\title{
Максим Сикал,
}

доиент кафедри адміністративного, ичивільного та господарського права і процесу Академії Державної пенітенціарної служби

\section{ПИТАННЯ ПРОКУРОРСЬКОГО НАГЛЯДУ ЗА ДОДЕРЖАННЯМ ЗАКОНІВ ПРИ ВИКОНАННІ СУДОВИХ РІШЕНЬ У КРИМІНАЛЬНИХ СПРАВАХ}

Проаналізовано правові та практичні аспекти здійснення прокурорського нагляду за додержанням законів при виконанні судових рішень у кримінальних справах. Виявлено проблемні питання прокурорського нагляду за додержанням законів установами виконання покарань. Запропоновано шляхи вдосконалення діючого законодавства у сфері діяльності органів прокуратури.

Ключові слова: прокурорський нагляд, права прокурорів, органи і установи виконання покарань.

Сыкал М.

Вопрос прокурорского надзора за соблюдением законов при исполнении судебных решений по уголовным делам

Проанализированы правовые и практические аспекты осуществления прокурорского надзора за соблюдением законов при исполнении судебных решений по уголовным делам. Выявлены проблемные вопросы прокурорского надзора за соблюдением законов учреждениями исполнения наказаний. Предложены пути совершенствования действующего законодательства в сфере деятельности органов прокуратуры.

Ключевые слова: прокурорский надзор, права прокуроров, органы и учреждения исполнения наказаний.

Sykal M.

Questions of prosecutor supervision in the context of laws in implementing judicial decisions in criminal matters

There are the legal and practical aspects of the implementation of prosecutorial supervision over observance of laws during the execution of judicial decisions in criminal cases are analyzed in the article. The problematic issues of the prosecutor's supervision over the observance of laws by the penitentiary institutions were revealed. The ways of improvement of the current legislation in the area of activity of the prosecutor's offices are offered.

Keywords: prosecutor's supervision, prosecutors'rights, penal institutions.

Актуальність дослідження. Удосконалення прокурорського нагляду за діяльністю органів і установ виконання покарань зумовлюється низкою факторів: по-перше, чинне законодавство України у повній мірі не відповідає міжнародним стандартам поводження із засудженими; по-друге, реалії сьогодення свідчать, що не викоренено практику неналежного поводження персоналу Державної кримінально-виконавчої служби України з особами, які взяті під варту та відбувають покарання в установах виконання покарань, а скарги засуджених на упереджене ставлення до них з боку персоналу не завжди розглядаються своєчасно та об'єктивно, по-третє, європейський напрям розвитку держави зумовлює формування як у засуджених, так і у персоналу переконання в тому, що має бути забезпечене людське ставлення до них; дотримання належних їм прав і свобод та реалізацію законних інтересів.

Так, згідно з офіційними даними, впродовж 9 місяців 2017 р. до органів прокуратури надійшло 2434 звернень щодо додержання кримінально-виконавчого законодавства, а за аналогічний період 2016 р. - 3107. Варто наголосити, що впродовж 2016 р. органами прокуратури виявлено ряд порушень закону та винесено документів прокурорського реагування, що були розглянуті: слідчими ізоляторами - 361; арештними домами - 16 ; виправними центрами - 186; виправними колоніями - 1393; виховними колоніями - 22, кримінально-виконавчими інспекціями - 743.

Аналіз останніх досліджень і публікацій. Вагомий внесок у розробку теоретико-правових аспектів контролю зробили вчені у галузі адміністративного права, зокрема В. Б. Авер'янов, О. Ф. Андрійко, О. В. Баклан, Ю. Ю. Басова, Л. В. Борець, С. Г. Братель, І. О. Васильєв, В. М. Гаращук, О. П. Гетьманець, С. Ф. Денисюк, В. Ю. Кобринський, В. К. Колпаков, О. В. Кузьменко, Д. В. Лученко, В. В. Новіков, П. В. Синицький, Л. П. Сушко, Д. П. Цвігун, В. В. Шемчук, О. С. Шморгун, Х. П. Ярмакі.

Особливої уваги заслуговують праці українських і зарубіжних вчених: Р. В. Алієва, Є. Ю. Бараша, О. Г. Боднарчука, А. О. Галая, С. К. Гречанюка, О. В. Гулак, С. В. Зливка, С. М. Зубарєва, А. П. Мукшименко, В. П. Пєткова, у яких досліджені окремі організаційно-правові аспекти діяльності органів і установ виконання покарань.

() Максим Сикал, 2018 
Сикал М.

Питання прокурорського нагляду за додержанням законів при виконанні судових рішень...

Зазначені вище науковці зробили вагомий внесок у теорію і практику здійснення різних видів контролю, натомість комплексного дослідження організаційно-правових засад прокурорського нагляду за діяльністю органів і установ виконання покарань не проводилося.

У зв’язку з цим існує потреба у поглибленому науковому дослідженні питань, що стосуються прокурорського нагляду за діяльністю органів і установ виконання покарань, у виробленні теоретичних і практичних положень щодо вдосконалення правових та організаційних засад його здійснення.

Метою статті (завданням) є виявлення проблемних питань прокурорського нагляду за додержанням законів установами виконання покарань, а також формулювання пропозицій щодо удосконалення діючого законодавства у сфері діяльності органів прокуратури.

Виклад основного матеріалу дослідження. Правові засади здійснення прокурорського нагляду за діяльністю органів і установ виконання покарань закріплені в Конституції України, Законі України «Про прокуратуру» та інших нормативно-правових актах. Слід зауважити, що у зв’язку з проведенням судової реформи 2 червня 2016 р. було прийнято Закон України «Про внесення змін до Конституції України (щодо правосуддя)» № 1401-VIII. Даним Законом було виключено розділ VII «Прокуратура», на зміну якого було прийнято статтю $131^{1}$, де визначено оновлені функції прокуратури, а саме: 1) підтримання публічного обвинувачення в суді; 2) організація і процесуальне керівництво досудовим розслідуванням, вирішення відповідно до закону інших питань під час кримінального провадження, нагляд за негласними та іншими слідчими і розшуковими діями органів правопорядку; 3) представництво інтересів держави в суді у виключних випадках і в порядку, що визначені законом [1].

Виходячи $з$ положень статті $131^{1}$ Конституції України можемо констатувати, що законодавець не вбачає доцільності у наявності таких функцій, як: 1) нагляд за додержанням законів при виконанні судових рішень у кримінальних справах, а також при застосуванні інших заходів примусового характеру, пов’язаних з обмеженням особистої свободи громадян; 2) представництво інтересів громадянина в суді.

Український нормотворець також переформулював функцію підтримання державного обвинувачення в суді на підтримання публічного обвинувачення в суді, а функцію нагляду за додержанням законів органами, що провадять оперативно-розшукову діяльність, дізнання, досудове слідство виклав як організація і процесуальне керівництво досудовим розслідуванням, вирішення відповідно до закону інших питань під час кримінального провадження, нагляд за негласними та іншими слідчими і розшуковими діями органів правопорядку.

Варто наголосити на тому, що відповідно до пункту 9 Перехідних положень Конституції України, прокуратура продовжує виконувати відповідно до чинних законів функцію нагляду за додержанням законів при виконанні судових рішень у кримінальних справах, - до набрання чинності законом про створення подвійної системи регулярних пенітенціарних інспекцій [2]. Означена функція визначена ст. 2 Закону України «Про прокуратуру» № 1697-VII від 14 жовтня 2014 року.

Що ж до створення подвійної системи регулярних пенітенціарних інспекцій, то тут буде слушним зазначити, що нормативно-правові акти, які б визначали таку систему контролю, відсутні, а підготовлений Міністерством юстиції проект Закону України «Про пенітенціарну систему» не містить жодної згадки про створення подвійної системи регулярних пенітенціарних інспекцій. А тому визначена Законом України «Про прокуратуру» функція з нагляду за додержанням законів при виконанні судових рішень у кримінальних справах буде вельми актуальною на сьогодні.

Відповідно до ст.. 104 Кримінально-виконавчого кодексу України № 1129-IV від 11 липня 2003 року, ст.. 18 Закону України «Про Державну кримінально-виконавчу службу України» № 2713-IV від 23 червня 2005 року, а також статті 5 Закону України «Про оперативно-розшукову діяльність» № 2135-ХII від 18 лютого 1992 року оперативні підрозділи органів і установ виконання покарань здійснюють оперативнорозшукову діяльність. А тому прокуратура буде здійснювати нагляд за додержанням законів оперативними підрозділами органів і установ виконання покарань при здійсненні оперативно-розшукової діяльності.

На офіційному сайті Генеральної прокуратури України містяться статистичні дані щодо нагляду за діяльністю органів і установ виконання покарань, а саме за 9 місяців 2017 року: звільнено за ініціативою прокурора 40 незаконно утримуваних осіб (за аналогічний період 2016 р. - 51); розглянуто 5924 документів прокурорського реагування з вжиттям заходів щодо усунення порушень закону (за аналогічний період 2016 р. - 6111); притягнуто до дисциплінарної, адміністративної, матеріальної відповідальності 4223 працівника (за аналогічний період 2016 р. - 4323).

Варто зазначити, що прокуратури наділені спеціальними правами для здійснення нагляду. Так, ст.. 24 Кримінально-виконавчого кодексу України надає право Генеральному прокурору, а також уповноваженим ним прокурорам і прокурорам, які здійснюють на відповідній території нагляд за додержанням законів 
при виконанні судових рішень у кримінальних справах без спеціального дозволу (акредитації) в будь-який час безперешкодно відвідувати установи виконання покарань для здійснення контролю та проведення перевірок (за бажанням - у супроводі до трьох медичних працівників для медичного огляду засуджених та до двох представників засобів масової інформації) [3].

Таке ж право закріплено і у ст. 26 Закону України «Про прокуратуру». Крім цього, дана стаття надає такі права прокурору: опитувати осіб, які перебувають в установах виконання покарань та слідчих ізоляторах; ознайомлюватися 3 документами, на підставі яких ці особи тримаються в таких місцях, засуджені або до них застосовано заходи примусового характеру; знайомитися з матеріалами, отримувати їх копії, перевіряти законність наказів, розпоряджень, інших актів відповідних органів і установ та в разі невідповідності законодавству вимагати від посадових чи службових осіб їх скасування та усунення порушень закону, до яких вони призвели, а також скасовувати незаконні акти індивідуальної дії; вимагати від посадових чи службових осіб надання пояснень щодо допущених порушень, а також вимагати усунення порушень та причин і умов, що їм сприяли, притягнення винних до передбаченої законом відповідальності; знайомитися з матеріалами виконавчого провадження щодо виконання судових рішень у кримінальних справах, робити з них виписки, знімати копії; вимагати від керівників органів вищого рівня проведення перевірок підпорядкованих і підконтрольних органів та установ попереднього ув'язнення, виконання покарань, застосування заходів примусового характеру; звертатися до суду з позовом (заявою) у визначених законом випадках [4].

Натомість варто наголосити, що прокурори час від часу допускають вчинення дій, що не охоплені вищезгаданим переліком прав прокурора. Наприклад, за результатами проведених працівниками Генеральної прокуратури України перевірок діяльності установ виконання покарань в Запорізькій області у листопаді 2017 р. 3 дільниці соціальної реабілітації до охоронної території Вільнянської виправної колонії № 20 повернуто трьох засуджених, які вчинили особливо тяжкі злочини, передбачені ч. 4 ст. 152 Кримінального кодексу України [5]. Працівниками прокуратури було зазначено, що адміністраціями установ виконання покарань допускалися випадки безпідставного застосування пільг у вигляді переведення засуджених до дільниць соціальної реабілітації за межі охоронної території виправних колоній без належного вивчення особистості засуджених. А також прокурорами акцентовано увагу на те, що Генеральна прокуратура України звертала увагу на аналогічні порушення у цій установі в травні 2017 р., однак жодних заходів працівниками Державної кримінально-виконавчої служби України у Запорізької області не вжито. Виходячи зі змісту сформульованого прокуратурою зауваження, ми можемо зробити висновок про те, що адміністрація Вільнянської виправної колонії № 20 порушила діюче законодавство при застосуванні пільги у вигляді переведення засуджених, які вчинили особливо тяжкі злочини, що передбачені ч. 4 ст. 152 Кримінального кодексу України, до дільниці соціальної реабілітації. Варто відзначити те, що дана установа являється колонією середнього рівня безпеки для чоловіків, які вперше засуджені до позбавлення волі за тяжкі та особливо тяжкі злочини, що має дільницю соціальної реабілітації.

У відповідності до частини 1 статті 101 Кримінально-виконавчого кодексу України засуджені, які стають на шлях виправлення, переводяться 3 колоній середнього рівня безпеки до дільниці соціальної реабілітації після фактичного відбуття не менше половини строку покарання, призначеного судом за особливо тяжкий злочин. Поряд із тим законодавець у частині 2 згаданої статті зазначив, що не підлягають переведенню до дільниці соціальної реабілітації: 1) особи, які мають достроково не зняті або не погашені у встановленому законом порядку стягнення, зазначені в абзацах 4, 6-10 статті 132 Кримінально-виконавчого кодексу України, протягом строку, визначеного статтею 134 Кримінально-виконавчого кодексу України; 2) інваліди першої та другої груп та особи, які досягли пенсійного віку; 3) особи, які не пройшли повний курс лікування венеричного захворювання, активної форми туберкульозу, психічного розладу, алкоголізму та наркоманії; 4) особи, яких засуджено за вчинення умисного злочину в період відбування покарання у виді арешту або обмеження волі [3].

Отже, можемо констатувати, що законодавець не передбачив підставу для відмови у застосуванні пільги у вигляді переведення засуджених, які вчинили особливо тяжкі злочини, що передбачені ч. 4 ст. 152 Кримінального кодексу України, до дільниці соціальної реабілітації. А тому висновок працівників прокуратури про те, що адміністраціями установ виконання покарань допускалися випадки безпідставного застосування пільг у вигляді переведення засуджених до дільниць соціальної реабілітації, зокрема у Вільнянській виправній колонії № 20, є таким, що не грунтується на діючому законодавстві. Як наслідок, вказівки прокурорів про переведення трьох засуджених, які вчинили особливо тяжкі злочини, передбачені ч. 4 ст. 152 Кримінального кодексу України, з дільниці соціальної реабілітації до охоронної території Вільнянської виправної колонії № 20 є нічим іншим, як вихід за межі наданих їм прав.

Варто наголосити на тому, що працівники управління нагляду за додержанням законів при виконанні судових рішень у кримінальних провадженнях та інших заходів примусового характеру у місцях неволі 
провели перевірку стану додержання вимог кримінально-виконавчого та іншого законодавства в установах Державної кримінально-виконавчої служби в Запорізькій області саме за дорученням Генерального прокурора України, про що зазначено на офіційному сайті Генеральної прокуратури України. Натомість прокурорський нагляд повинен здійснюватися систематично, як це зазначено у пункті 13 Наказу № 161 від 20 квітня 2016 року «Про організацію діяльності прокурорів з нагляду за додержанням законів при виконанні судових рішень у кримінальних справах, а також при застосуванні інших заходів примусового характеру, пов'язаних з обмеженням особистої свободи громадян», а саме те, що прокурор повинен не рідше одного разу на місяць здійснювати особистий прийом взятих під варту та засуджених осіб, перевіряти стан додержання законодавства щодо забезпечення їх права на листування та звернення, обліку інформації про злочини та події, законність дій службових осіб, накладення дисциплінарних стягнень [6]. А якщо ж прокурорський нагляд буде здійснюватися за вказівками Генерального прокурора України, то у такому випадку мета прокурорського нагляду буде зводитись саме до виявлення удаваних недоліків.

Висновки. Враховуючи вищевикладене, пропонується доповнити частину першу ст.. 43 Закону України «Про прокуратуру» десятою підставою для притягнення прокурора до дисциплінарної відповідальності, а саме за надання обов'язкових для виконання вказівок за результатами здійснення прокурорського нагляду, що не грунтуються на вимогах діючого законодавства.

\section{Список використаних джерел}

1. Про внесення змін до Конституизї України (щзодо правосуддя): Закон України № 1401-VIII від 2.06.2016 // [Електронний ресурс]. - Режим доступу : zakon.rada.gov.ua/go/1401-19.

2. Конституція України : Закон № 254 к/96-ВР від 28.06.1996 р. // [Електронний ресурс]. - Режим доcmyny : http://zakon5.rada.gov.ua/laws/show/254\%D0\%BA/96-\%D0\%B2\%D1\%80.

3. Кримінально-виконавчий кодекс Украӥни : Закон України № 1129-IV від 11.07.2003 // [Електронний ресурс] - Режим доступу : zakon.rada.gov.ua/go/1129-15.

4. Про прокуратуру: Закон Украйни № 1697-VII від 14.10.2014 // [Електронний ресурс]. - Режим доступу : zakon.rada.gov.ua/go/1697-18.

5. Генеральна прокуратура Украйни : [Електронний ресурс]. - Режим доступу : https://www.gp.gov.ua/ual news.html? $m=$ publications\&_c=view\&_t=rec\&id=21922.

6. Про організачію діяльності прокурорів з нагляду за додержанням законів при виконанні судових рішень у кримінальних справах, а також при застосуванні інших заходів примусового характеру, пов'язаних з обмеженням особистої свободи громадян : Наказ № 161 від 20.04.2016 // [Електронний ресурс]. - Режим достуny : https://www.gp.gov.ua/ua/gl.html?_m=publications\&_t=rec\&id.

\section{References}

1. Zakon Ukrainy «Pro vnesennya zmin do Konstytutsiyi Ukrayiny (shchodo pravosuddya)» [The Law of Ukraine «On Amendments to the Constitution of Ukraine (on Justice)»]. (n.d.). zakon.rada.gov.ua. Retrieved from zakon.rada.gov.ua/go/1401-19 [in Ukrainian].

2. Konstytutsiya Ukrayiny [Constitution of Ukraine]. (n.d.). zakon.rada.gov.ua. Retrieved from http://zakon5. rada.gov.ua/laws/show $/ 254 \%$ D0\%BA/96-\%D0\%B2\%D1\%80 [in Ukrainian].

3. Kryminal'no-vykonavchyy kodeks Ukrayiny [The Criminal-Executive Code of Ukraine]. (n.d.). zakon.rada. gov.ua. Retrieved from zakon.rada.gov.ua/go/1129-15 [in Ukrainian].

4. Zakon Ukrainy «Pro prokuraturu» [The Law of Ukraine «About the prosecutor $s$ office»]. (n.d.). zakon.rada. gov.ua. Retrieved from zakon.rada.gov.ua/go/1697-18 [in Ukrainian].

5. 5. Sayt Heneral'noyi prokuratury Ukrayiny: [Website of the General Prosecutor's Office of Ukraine]. (n.d.). www.gp.gov.ua. Retrieved from https://www.gp.gov.ua/ua/news.html?_m=publications\&_c=view\&_ $t=$ rec\&id=21922 [in Ukrainian].

6. Nakaz Heneral'noyi prokuratury Ukrayiny «Pro orhanizatsiyu diyal'nosti prokuroriv z nahlyadu za doderzhannyam zakoniv pry vykonanni sudovykh rishen' u kryminal'nykh spravakh, a takozh pry zastosuvanni inshykh zakhodiv prymusovoho kharakteru, pov"yazanykh z obmezhennyam osobystoyi svobody hromadyan» [The order of General Prosecutor's Office of Ukraine "On the organization of the activities of prosecutors to supervise the observance of laws in the execution of judicial decisions in criminal cases, as well as in the application of other coercive measures related to restrictions on personal freedom of citizens»]. (n.d.). www. gp.gov.ua. Retrieved from https://www.gp.gov.ua/ua/gl.html?_m=publications\&_t=rec\&id [in Ukrainian].

Стаття надійшла до редакції 18.01.2018. 